\title{
Metastatic Intraocular Tumor Due to Colorectal Adenocarcinoma: Case Report and Literature Review
}

\author{
Deivy Cruzado-Sanchez ${ }^{1}$, MD; Luis A. Saavedra-Mejia ${ }^{2}$, MD; Walter A. Tellez ${ }^{2}$, MD \\ Grissnery Maquera-Torres ${ }^{3}$, MD; Solon Serpa-Frias ${ }^{1}$, MD \\ ${ }^{1}$ Ophthalmic Oncology Service, Instituto Nacional de Enfermedades Neoplásicas, Lima, Peru \\ ${ }^{2}$ Sociedad Científica de Estudiantes de Medicina Villarrealinos, Universidad Nacional Federico Villarreal, Lima, Peru \\ ${ }^{3}$ Pathology Service, Instituto Nacional de Enfermedades Neoplásicas, Lima, Peru
}

ORCID:

Deivy Cruzado-Sanchez: https://orcid.org/0000-0003-0826-8928

\section{Abstract}

Purpose: To describe the clinical and histopathological findings of a case of intraocular metastasis due to colorectal adenocarcinoma and to carry out a literature review.

Case Report: A 64-year-old man with a history of tumor resection due to infiltrating colorectal adenocarcinoma three years previously sought ophthalmological care because of severe ocular pain without response to medical treatment and progressive vision loss in the left eye. On ultrasonographic examination, there was a heterogeneous intraocular choroidal tumor, which occupied approximately $40 \%$ of the vitreous cavity, as well as peritumoral serous retinal detachment. The patient underwent left eyeball enucleation. The histopathological diagnosis was metastatic tubular adenocarcinoma involving the retina and choroid that partially infiltrated the sclera and the proximal optic nerve.

Conclusion: The present case highlights a rare pathological entity associated with variable therapeutic schemes and survival times and poor prognosis in patients with metastatic intraocular tumors due to colorectal adenocarcinoma.

Keywords: Colorectal Neoplasms; Eye Neoplasms; Neoplasm Metastasis

J Ophthalmic Vis Res 2020; 15 (4): 565-570

\section{INTRODUCTION}

Colon cancer is the second cause of death associated with cancer in developed countries,

Correspondence to:

Deivy Cruzado-Sanchez, MD. 2520 Angamos Avenue, Ophthalmic Oncology Service, Instituto Nacional de Enfermedades Neoplásicas, 15038 Lima, Peru. E-mail: dcruzados@gmail.com

Received: 24-02-2019 Accepted: 13-01-2020

\section{Access this article online}

Website: https://knepublishing.com/index.php/JOVR

DOI: 10.18502/jovr.v15i4.7794 representing $9 \%$ of all cancer estimated deaths; ${ }^{[1]}$ while in developing countries like Peru, it is the fifth cause of death, accounting for 6 deaths per 100,000 inhabitants. ${ }^{[2]}$ The most frequent sites of metastasis are liver (77\%), peritoneum (25\%), and lungs (22\%), while intraocular involvement is infrequent and rarely reported. ${ }^{[3-5]}$

This is an open access journal, and articles are distributed under the terms of the Creative Commons Attribution-NonCommercial-ShareAlike 4.0 License, which allows others to remix, tweak, and build upon the work non-commercially, as long as appropriate credit is given and the new creations are licensed under the identical terms.

How to cite this article: Cruzado-Sánchez D, Saavedra-Mejía LA, Tellez WA, Maquera-Torres G, Serpa-Frias S. Metastatic Intraocular Tumor Due to Colorectal Adenocarcinoma: Case Report and Literature Review. J Ophthalmic Vis Res 2020;15:565-570. 
The aim of this report is to describe the clinical and histopathological findings of a case of intraocular metastasis from colorectal adenocarcinoma and to carry out a literature review.

\section{CASE REPORT}

The patient was a 64-year-old man with six months of severe and progressive vision loss in the left eye associated with severe ocular pain. He had a history of resection of a moderately differentiated colorectal adenocarcinoma with muscle layer involvement, invasive borders, and involvement in 3 of the 25 regional lymph nodes (T3N1MO) three years ago. He refused complementary treatment with chemotherapy at that time (Figures $1 \mathrm{~A} 1$ and 1A2).

The ophthalmological examination showed a visual acuity (VA) of 20/20 in the right eye and no light perception in the left eye. Intraocular pressure was $16 \mathrm{mmHg}$ in the right eye and $50 \mathrm{mmHg}$ in the left eye. Biomicroscopic examination showed moderate conjunctival hyperemia, mydriatic and unreactive pupil, moderate corneal edema, and moderate crystalline opacity in the left eye and unremarkable findings in the right eye. Funduscopy revealed extensive whitish tumor mass with multiple hemorrhagic foci on its surface, moderate vitreous opacity and retinal detachment in the left eye. On ultrasonographic examination, there was a heterogeneous intraocular choroidal tumor, which occupied approximately $40 \%$ of the vitreous cavity, as well as peritumoral serous retinal detachment (Figure 2). Computed tomography preformed for metastasis work-up demonstrated tumoral lesions in the lungs.

He was diagnosed as a secondary noncontrolled glaucoma due to probable metastatic choroidal tumor. He received maximum antihypertensive ocular treatment in the left eye with poor response and persistence of pain. Due to the evidence of a blind, painful eye with a large intraocular tumor, left eyeball enucleation was performed with patient's informed consent. The histopathological diagnosis was metastatic tubular adenocarcinoma involving the retina and choroid, partially infiltrating the sclera and the proximal optic nerve. Immunohistochemical study was positive to CDX2; some tumor cells expressed CK20 focally, and the tumor was negative for
CK7. All these findings were consistent with a primary colorectal adenocarcinoma as the source of metastasis (Figures 1B1-1B5).

Medical oncology team assessed the patient. Treatment with chemotherapy and palliative radiotherapy was indicated, but he refused it and just accepted palliative pain therapy. He died six months after the enucleation.

\section{DISCUSSION}

Metastasis of colorectal carcinoma to the eye is infrequent, $^{[3]}$ and it is associated with advanced stages of the disease with an unfavorable prognosis and poor survival. ${ }^{[6]}$

We performed a literature review through a systematic search in PubMed and Google Scholar using an appropriate search strategy for each database (supplementary material 1) and reviewed the references of the reports included in the systematic search to increase the chances of identifying all reported cases of intraocular metastasis due to colorectal adenocarcinoma. We included 23 case reports and 1 case series (Table 1), accounting for 25 cases, for which 19 patients presented with metastasis only to the choroid, ${ }^{[4-23]}$ three with metastasis only to the retina, ${ }^{[24-26]}$ one with metastasis to the retina and choroid, ${ }^{[27]}$ one with metastasis to the sclera, retina, and optic nerve, ${ }^{[28]}$ and one with metastasis to the choroid and optic nerve. ${ }^{[29]}$ The average age was 55.2 years (ranging from 30 to 80 years), and 15 patients were men. Regarding the source of the primary neoplasia, 12 were derived from the colon, 12 from the rectum, and 1 was colorectal. However, most of the papers did not report the TNM staging.

The average time of detection of intraocular metastasis after the diagnosis of the primary colorectal neoplasm was 24.7 months (ranging from immediately up to 96 months); only in five cases was the diagnosis of intraocular metastasis made at the same time as the primary colorectal neoplasm diagnosis. ${ }^{[8,10,13,18,24]}$ In addition to intraocular metastasis, an involvement of other organs have also been found, such as liver, lung, skin, bone, brain, and cerebellum (Table 1). In the current case, intraocular metastasis was detected 36 months after the diagnosis of the primary tumor.

In the cases reported in the literature (Table 1), the most frequent reason for ophthalmological consultation was some type of vision dysfunction 


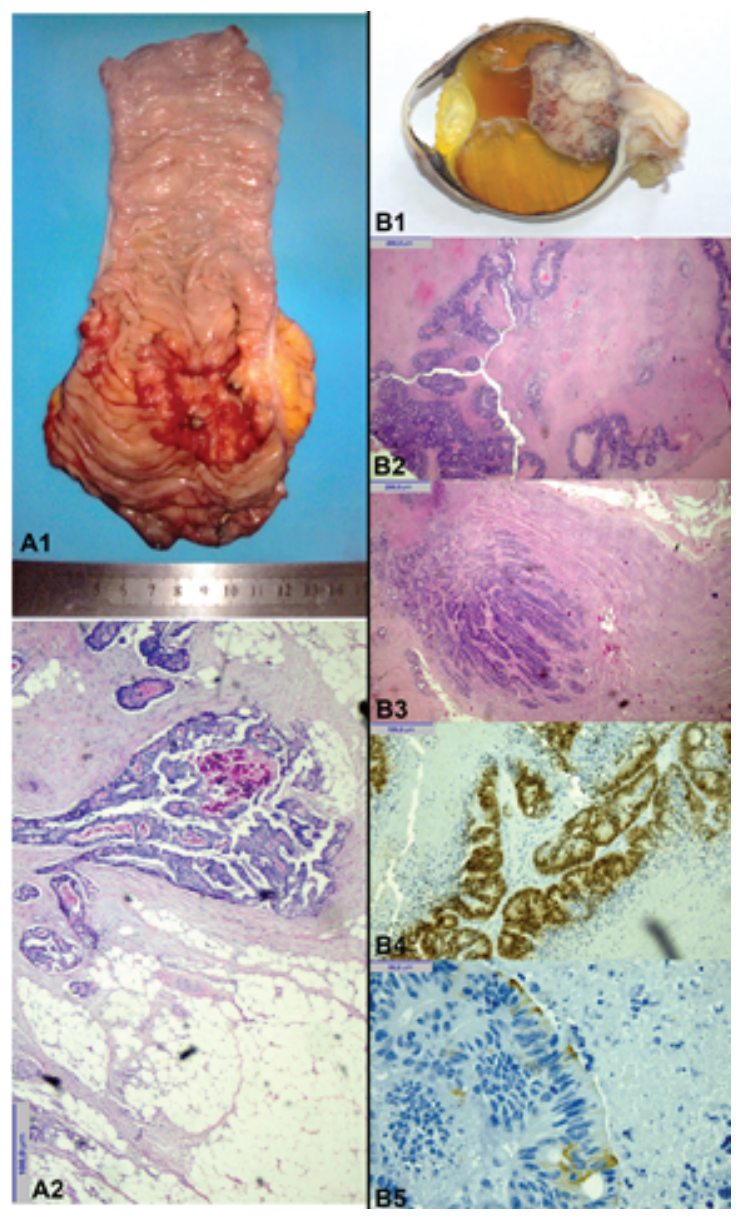

Figure 1. Primary neoplasms from A1 to A3. (A1) Colonic macroscopy of a single tumor above the junction of the rectum and sigmoid. (A2) Tubular adenocarcinoma moderately differentiated in the submucosal layer of colon pT3N1b. Intraocular metastasis from B1 to B5. (B1) Eyeball with exophytic tumor. H\&E staining. (B2) Metastasis of tubular adenocarcinoma in the retina. (B3) Metastasis of tubular adenocarcinoma in the optic nerve. (B4) Positive nuclear staining for CDX2. (B5) Positive focal expression of CK20.

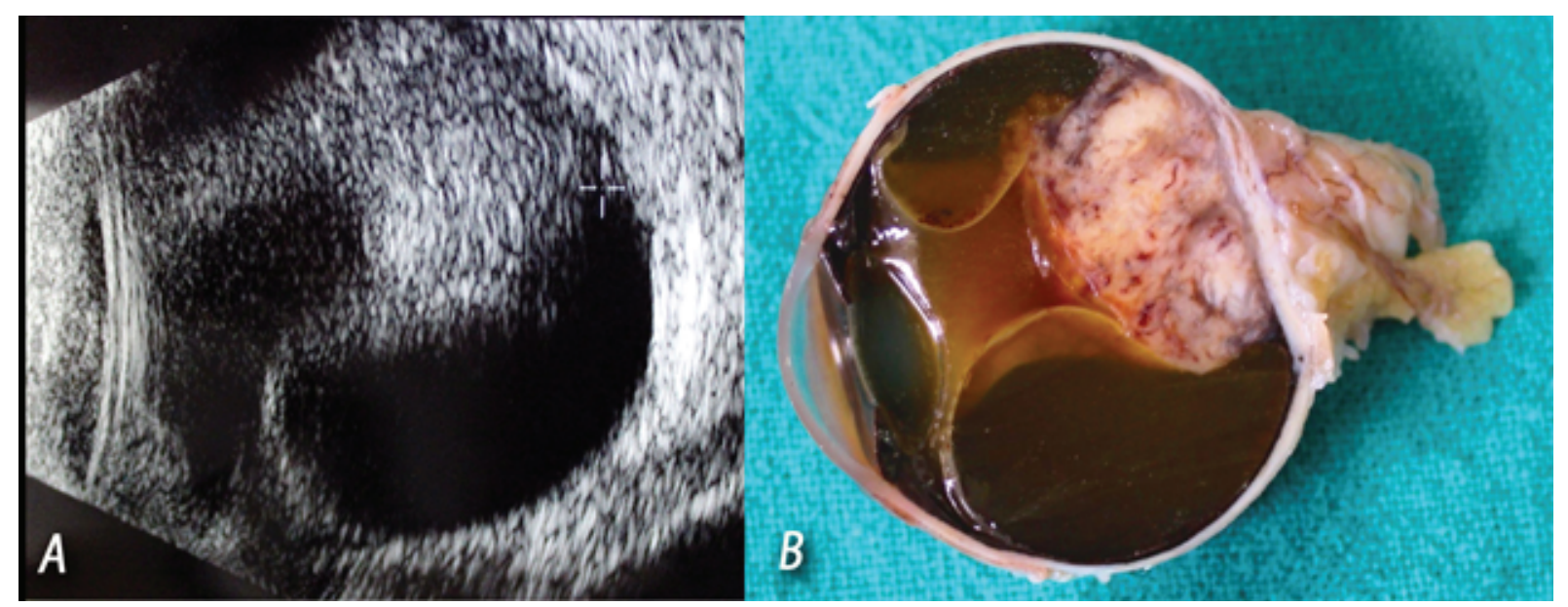

Figure 2. (A) Ocular ultrasound demonstrating a heterogeneous intraocular choroidal tumor associated with retinal detachment. (B) Enucleated surgical tissue from the eye with a whitish tumor mass with signs of hemorrhage. 
Table 1. Characteristics of previous intraocular metastasis cases due to colorectal adenocarcinoma reported in the literature

\begin{tabular}{|c|c|c|c|c|c|c|c|c|c|c|c|}
\hline \multirow[t]{2}{*}{ Author } & \multirow{2}{*}{$\begin{array}{c}\text { Year of } \\
\text { publication }\end{array}$} & \multirow[t]{2}{*}{ Sex } & \multirow[t]{2}{*}{ Age } & \multicolumn{2}{|c|}{ Colorectal cancer } & \multicolumn{4}{|c|}{ Intraocular metastasis } & \multirow{2}{*}{$\begin{array}{l}\text { Other sites of } \\
\text { metastasis }\end{array}$} & \multirow{2}{*}{$\begin{array}{c}\text { Survival } \\
\text { time } \\
\text { (months) }\end{array}$} \\
\hline & & & & $\begin{array}{l}\text { Primary } \\
\text { lesion }\end{array}$ & $\begin{array}{l}\text { TNM or } \\
\text { stage }\end{array}$ & $\begin{array}{l}\text { Intraocular } \\
\text { site }\end{array}$ & $\begin{array}{l}\text { Time to } \\
\text { diagnosis } \\
\text { (months) }\end{array}$ & Symptom & Treatment & & \\
\hline Kennedy ${ }^{[24]}$ & 1958 & $M$ & 51 & Rectosigmoid & NS & Retina & $\mathrm{s}$ & $\begin{array}{l}\text { Blurred } \\
\text { vision }\end{array}$ & Enucleation & None & 9 \\
\hline Howard ${ }^{[2] * *}$ & 1968 & M & 63 & Colon & NS & $\begin{array}{l}\text { Retina, } \\
\text { choroid }\end{array}$ & 36 & $\begin{array}{c}\text { Visual } \\
\text { disturbance }\end{array}$ & Enucleation & Orbit & 16 \\
\hline Cole $^{[7] *}$ & 1985 & $\mathrm{~F}$ & 48 & Rectum & T4a & Choroid & 23 & $\begin{array}{l}\text { Blurred } \\
\text { vision }\end{array}$ & $\mathrm{RT}, \mathrm{CT}$ & Lung & 4 \\
\hline $\operatorname{Tano}^{[8] *}$ & 1989 & $M$ & 30 & Rectum & NS & Choroid & s & $\begin{array}{l}\text { Blurred } \\
\text { vision }\end{array}$ & Enucleation & Bone, skin & 4 \\
\hline Endo $^{[9] *}$ & 1997 & $\mathrm{~F}$ & 49 & Rectum & NS & Choroid & 84 & Flashes & Enucleation & Liver, lung & 3 \\
\hline Ward $^{[10]}$ & 2000 & $\mathrm{~F}$ & 52 & Colon & NS & Choroid & s & Vision loss & None & Intraabdominal & 1 \\
\hline Nakamura ${ }^{[11]}$ & 2002 & M & 79 & Colon & Illb & Choroid & 18 & $\begin{array}{l}\text { Blurred } \\
\text { vision }\end{array}$ & CT & Lung & NS \\
\hline Fujiwara $^{[12] *}$ & 2004 & M & 53 & Rectum & NS & Choroid & 30 & Vision loss & $\mathrm{RT}, \mathrm{CT}$ & $\begin{array}{l}\text { Liver, lung, } \\
\text { bone }\end{array}$ & 1 \\
\hline Linares $^{[13]}$ & 2004 & M & 47 & Rectum & NS & Choroid & s & $\begin{array}{l}\text { Blurred } \\
\text { vision }\end{array}$ & $\mathrm{RT}, \mathrm{CT}$ & Liver, lung & 9 \\
\hline Apte $^{[25]}$ & 2005 & M & 39 & Colon & NS & Retina & 3 & $\begin{array}{c}\text { Visual } \\
\text { disturbance }\end{array}$ & $\mathrm{RT}, \mathrm{CT}$ & Liver, lung & 7 \\
\hline Hisham $^{[28]}$ & 2006 & $\mathrm{~F}$ & 32 & Rectum & NS & $\begin{array}{l}\text { Sclera, } \\
\text { retina, optic } \\
\text { nerve }\end{array}$ & 10 & Ocular pain & RT & $\begin{array}{l}\text { Spine, breast, } \\
\text { orbit }\end{array}$ & 0.5 \\
\hline $\mathrm{Kuo}^{[14]}$ & 2008 & $\mathrm{~F}$ & 65 & Colon & NS & Choroid & 20 & Vision loss & $\begin{array}{c}\text { Intravitreous } \\
\text { Bev }\end{array}$ & Brain & 5 \\
\hline Sashiyama ${ }^{[15]}$ & 2010 & $M$ & 49 & Rectum & NS & Choroid & 15 & Vision loss & CT & Lung, bone & 11 \\
\hline $\operatorname{Lin}^{[16]}$ & 2010 & M & 43 & Colon & NS & Choroid & 96 & Vision loss & $\begin{array}{c}\mathrm{CT}, \\
\text { intravitreous } \\
\text { Bev }\end{array}$ & Bone & 4 \\
\hline Neale $e^{[17]}$ & 2010 & $M$ & 43 & Rectum & T2NOMO & Choroid & 18 & $\begin{array}{l}\text { Blurred } \\
\text { vision }\end{array}$ & NS & $\begin{array}{l}\text { Lung, pelvis, } \\
\text { brain }\end{array}$ & NS \\
\hline Miyake ${ }^{[18] *}$ & 2012 & $M$ & 74 & Rectum & NS & Choroid & $\mathrm{s}$ & Vision loss & CT & Liver, lung & 8 \\
\hline$T e i^{[19]}$ & 2014 & M & 60 & Rectum & $\mathrm{T} 1$ & Choroid & 30 & Floaters & RT & Lung & 27 \\
\hline \multirow[t]{2}{*}{ Maudgi|l[20] } & 2015 & $\mathrm{~F}$ & 57 & Colon & NS & Choroid & 18 & Vision loss & $\begin{array}{c}\text { Intravitreous } \\
\text { Bev }\end{array}$ & NS & NS \\
\hline & 2015 & M & 80 & Colon & NS & Choroid & 6 & Vision loss & $\begin{array}{c}\text { Intravitreous } \\
\text { Bev }\end{array}$ & Liver & NS \\
\hline Kawhaja $^{[4]}$ & 2015 & $\mathrm{~F}$ & 60 & Rectum & T3N1MO & Choroid & 42 & Flashes & $\begin{array}{c}\mathrm{RT}, \mathrm{CT}, \\
\text { systemic Bev }\end{array}$ & Lung & 31 \\
\hline $\mathrm{Huo}^{[21]}$ & 2015 & $\mathrm{~F}$ & 51 & Colon & T3N1MO & Choroid & 27 & $\begin{array}{l}\text { Ocular } \\
\text { redness, } \\
\text { foreign } \\
\text { body } \\
\text { sensation }\end{array}$ & RT & Lung, bone & 2.5 \\
\hline Nookala ${ }^{[26]}$ & 2016 & $M$ & 56 & Colon & T3NOMx & Retina & 25 & $\begin{array}{l}\text { Vision loss } \\
\text { and ocular } \\
\text { pression } \\
\text { sensation }\end{array}$ & RT & Liver, lung & NS \\
\hline $\operatorname{Boss}^{[22]}$ & 2016 & $\mathrm{~F}$ & 68 & Rectum & T3NOMx & Choroid & 96 & $\begin{array}{l}\text { Floaters } \\
\text { and flashes }\end{array}$ & $\begin{array}{c}\text { intravitreous } \\
\text { Bev }\end{array}$ & $\begin{array}{l}\text { Lung, } \\
\text { cerebellum }\end{array}$ & NS \\
\hline $\mathrm{Ha}^{[23]}$ & 2016 & $\mathrm{~F}$ & 78 & Colon & T3NOMO & Choroid & 6 & $\begin{array}{c}\text { Visual } \\
\text { disturbance }\end{array}$ & CT & Lung, skin & 8 \\
\hline Walker ${ }^{[29]}$ & 2017 & $M$ & 54 & Colon & T1NOMO & $\begin{array}{l}\text { Choroid, } \\
\text { optic nerve }\end{array}$ & 16 & Vision loss & $\begin{array}{c}\text { RT, systemic } \\
\text { Bev, CT, } \\
\text { photodynamic } \\
\text { therapy }\end{array}$ & Lung & 24 \\
\hline Present case & 2018 & $M$ & 64 & Rectosigmoid & T3N1MO & $\begin{array}{l}\text { Choroid, } \\
\text { retina, optic } \\
\text { nerve, } \\
\text { sclera }\end{array}$ & 36 & $\begin{array}{l}\text { Ocular pain } \\
\text { and vision } \\
\text { loss }\end{array}$ & Enucleation & Lung & 6 \\
\hline
\end{tabular}


Supplementary Material 1. Literature review through a systematic search of PubMed and Google Scholar

\begin{tabular}{llc}
\hline & & Date \\
\hline PubMed & ("neoplasm metastasis"[MeSH Terms] OR "metastasis"[Title/Abstract] & October 2018 \\
& OR "metastases"[Title/Abstract] OR "ocular metastasis"[Title/Abstract] & \\
& OR "intraocular metastasis"[Title/Abstract]) AND ("choroid"[MeSH & \\
& Terms] OR "choroid"[Title/Abstract] OR "retina"[MeSH Terms] OR & \\
& "retina"[Title/Abstract]) AND ("case reports"[Publication Type] OR "case & \\
& study"[Title/Abstract] OR "case report"[Title/Abstract]) & October 2018 \\
& ("neoplasm metastasis" OR "metastasis" OR "metastases" OR "ocular & \\
Google Scholar & metastasis" OR "intraocular metastasis") AND ("choroid" OR "retina") & \\
& AND ("colorectal cancer" OR "colon cancer" OR "colonic neoplasm" OR & \\
& "colonic cancer") & \\
\hline
\end{tabular}

(decreased VA, blurred vision, floaters or flashes), whereas in the present case, the patient had severe ocular pain related to uncontrolled secondary glaucoma in addition to vision loss, similar to a case reported in Malaysia. ${ }^{[28]}$

Four cases of eyeball enucleation have been reported in the literature. ${ }^{[8,9,24,27]}$ Currently, enucleation is considered a reserved therapeutic option for intraocular malignant tumors in advanced stages with extensive ocular involvement and severe pain due to secondary glaucoma. $^{[30,31]}$ In the present case, enucleation was performed because of the extensive ocular involvement, absent visual function, secondary uncontrollable glaucoma, and the refusal of the patient to submit to other therapeutic proposals.

The survival time ranged from 14 days to 31 months after the diagnosis of intraocular metastasis in previously published reports (Table 1). In the present case, the patient's survival time was six months. In previous cases treated with enucleation, $[8,9,24,27]$ the survival time ranged from 3 to 16 months, while longer survival times were reported in patients treated with radiotherapy, chemotherapy, and systemic bevacizumab treatment (24 and 31 months).

In the present case, the immunohistochemical assessment of the intraocular tumor was positive for CDX2, focally positive for CK20, and negative for CK7. These results showed an immunohistochemical profile with high sensitivity and specificity for colorectal adenocarcinoma (CDX2+, CK7-/CK20+). ${ }^{[32]}$ The focal positivity of the CK20 marker is consistent with the pattern of expression in colorectal adenocarcinoma, with greater expression in rectal carcinomas than in nonrectal carcinomas, ${ }^{[32]}$ so the focal expression in this case may be due to the greater expression of this marker in tumor cells derived from the rectum than in those derived from the sigmoid colon.

In conclusion, the present case highlights a rare pathological entity that has been increasingly reported in recent years and has been observed in relation to variable therapeutic schemes and survival times, and simultaneous metastasis to other organs has also been observed. Therefore, clinicians should consider the possibility of intraocular metastasis when managing patients with colorectal cancer in advanced stages.

\section{REFERENCES}

1. Siegel $\mathrm{R}$, Miller $\mathrm{K}$, Jemal A. Cancer statistics, 2017. CA Cancer J Clin 2017;67:7-30.

2. Dirección General de Epidemiología. Análisis de la situación del cáncer en el Perú 2013. Ministerio de Salud [Internet]. Lima: Ashka; 2013 [cited August 28, 2017]. Available from: http://www.dge.gob.pe/portal/docs/ asis_cancer.pdf

3. Hess KR, Varadhachary GR, Taylor SH, Wei W, Raber MN, Lenzi R, et al. Metastatic patterns in adenocarcinoma. Cancer 2006;106:1624-1633.

4. Khawaja M, Minturn J, Spittler A, Chiorean E. Ocular metastasis of colorectal cancer: an uncommon presentation of a common malignancy. Hematol Oncol Stem Cell Ther 2015;8:176-180.

5. Shields CL, Shields JA, Gross NE, Schwartz GP, Lally SE. Survey of 520 eyes with uveal metastases. Ophthalmology 1997;104:1265-1276.

6. Konstantinidis L, Damato B. Intraocular metastases - a review. Asia Pac J Ophthalmol 2017;6:208-214.

7. Cole MD, Farah NB. The choroid - an unusual site for metastasis in patients with adenocarcinoma of the rectum - a case report. Eur J Surg Oncol 1985;11:275-278.

8. Tano S, Hayashi H, Momoeda S. Metastasis of rectal carcinoma to the choroid: a case report. Nihon Ganka Kiyo 1989;40:1284-1288.

9. Endo H, Tajika T, Takebayashi H, Shiota H, Yoshida M, Kudo E. A case report of choroidal metastasis from rectal cancer. Ganka Rinsho Iho 1997;91:1141. 
10. Ward SD, Byrne BJ, Kincaid MC, Mann ES. Ultrasonographic evidence of a mushroom-shaped choroidal metastasis. Am J Ophthalmol 2000;130:681682.

11. Nakamura H, Harada A, Sakakibara T, Ishikawa T, Yaguchi T, Murakami Y. Metastatic choroidal tumor from cancer of the ascending colon - a case report. J Jpn Surg Assoc 2002;63:1031-1035.

12. Fujiwara T, Machida S, Murai K, Tazawa $\mathrm{Y}$, Baba $\mathrm{Y}$, Shimooki O. A case of choroidal tumor metastasized from rectal cancer. Ganka 2004;46:1099-1103.

13. Linares P, Castanon C, Vivas S, Diz P, Garcia-Palomo A, Llano $\mathrm{C}$, et al. Bilateral choroidal metastasis as the initial manifestation of a rectal cancer. J Gastroenterol Hepatol 2004;19:726-727.

14. Kuo IC, Haller JA, Maffrand R, Sambuelli RH, Reviglio VE. Regression of a subfoveal choroidal metastasis of colorectal carcinoma after intravitreous bevacizumab treatment. Arch Ophthalmol 2008;126:1311-1313.

15. Sashiyama H, Abe $Y$, Sasagawa S, Hanada H, Hatori $Y$, Kubota $\mathrm{M}$, et al. A case of choroidal metastasis from rectal cancer manifesting visual loss as the initial recurrence symptom. Jpn J Gastroenterol Surg 2010;43:746-751.

16. Lin CJ, Li KH, Hwang JF, Chen SN. The effect of intravitreal bevacizumab treatment on choroidal metastasis of colon adenocarcinoma - case report. Eye 2010;24:1102-1103.

17. Neale JA, Valsdottir E, Zeger E, Shields C, Marks J. Cerebral and choroidal metastases with retinal detachment, secondary to rectal cancer: a case report. World J Colorectal Surg 2010;2:1-9.

18. Miyake E, Moriwaki M, Sunada T, Takemura J. Regression of choroidal metastasis from rectal cancer following chemotherapy. Atarashii Ganka 2012;29:701-704.

19. Tei M, Wakasugi M, Akamatsu H. Choroidal metastasis from early rectal cancer: case report and literature review. Int J Surg Case Rep 2014;5:1278-1281.

20. Maudgil A, Sears KS, Rundle PA, Rennie IG, Salvi SM. Failure of intravitreal bevacizumab in the treatment of choroidal metastasis. Eye 2015;29:707-711.

21. Huo SM, An HJ, Lee JE, Eum S, Kim MY, Jang YN, et al. Choroidal metastasis from colon cancer treated with palliative radiotherapy. Korean J Med 2015;89:723-727.
22. Boss JD, Lieu P, Tewari A. Effect of treatment of rectal cancer metastasis with intravitreal bevacizumab (Avastin) in a patient with subretinal fluid and macular oedema: short-term follow-up. BMJ Case Rep 2016;2016. doi: 10.1136/bcr-2016-216273

23. Ha JY, Oh EH, Jung MK, Park SE, Kim JT, Hwang IG. Choroidal and skin metastases from colorectal cancer. World J Gastroenterol 2016;22:9650-9653.

24. Kennedy RJ, Rummel WD, McCarthy JL, Hazard JB. Metastatic carcinoma of the retina; report of a case and the pathologic findings. AMA Arch Ophthalmol 1958;60:12-18.

25. Apte RS, Dibernardo C, Pearlman JR, Patel S, Schachat $A P$, Green WR, et al. Retinal metastasis presenting as a retinal hemorrhage in a patient with adenocarcinoma of the cecum. Arch Ophthalmol 2005;123:850-853.

26. Nookala R, Batchu VV, Lee HM, Loghmani A, Chhabra GS. Difficult diagnosis of colon adenocarcinoma metastasis to retina: a case report and literature review. Int J Hematol Oncol Stem Cell Res 2016;10:186-190.

27. Howard GM. Retinal hole in an eye with choroidal metastasis. Trans Am Acad Ophthalmol Otolaryngol 1968;72:186-190.

28. Hisham RB, Thuaibah H, Gul YA. Mucinous adenocarcinoma of the rectum with breast and ocular metastases. Asian J Surg 2006;29:95-97.

29. Walker CR, Reichstein DA. Bilateral metastases of colorectal cancer to the choroid and optic disc. Int $J$ Ophthalmol Vis Sci 2017;2:65-68.

30. Koylu MT, Gokce G, Uysal Y, Ceylan ML, Akıncıoglu D, Gunal A. Indications for eye removal surgeries. A 15-year experience at a tertiary military hospital. Saudi Med J 2015;36:2015-2019.

31. Kanthan GL, Jayamohan J, Yip D, Conway RM. Management of metastatic carcinoma of the uveal tract: an evidence-based analysis. Clin Exp Ophthalmol 2007;35:553-565.

32. Bayrak R, Haltas H, Yenidunya S. The value of CDX2 and cytokeratins 7 and 20 expression in differentiating colorectal adenocarcinomas from extraintestinal gastrointestinal adenocarcinomas: cytokeratin 7-/20+ phenotype is more specific than CDX2 antibody. Diagn Pathol 2012;7:9. 